\title{
Feasibility of Caging Material for True-To-Type Seed Production in Papaya (Carica papaya L.) under New Alluvial Zone of West Bengal, India
}

\author{
J. Uchoi ${ }^{1 *}$, Ezekiel Reang ${ }^{2}$ and S.K. Sarkar ${ }^{3}$ \\ ${ }^{1}$ ICAR-Central Arid Zone Research Institute (CAZRI), RRS, Jaisalmer-345001 \\ ${ }^{2}$ College of Agriculture, Tripura University, Lembucherra, Tripura - 799210, India \\ ${ }^{3}$ Department of Fruits and Orchard Management, Bidhan Chandra Krishi Viswavidyalaya, \\ Nadia - 741252, India \\ *Corresponding author
}

\begin{abstract}
A B S T R A C T
Keywords

Carica papaya, Seed production, Net, True to type, Fruit set

\section{Article Info}

Accepted: 06 May 2018 Available Online: 10 June 2018

Field experiments were conducted to test the feasibility of using different caging material viz. perforated $(3 \%)$ polyethylene sheet (200gauge), nylon net $(1.2 \mathrm{~mm})$, butter paper bag including control (open pollination) for true to type seed production in Local selection-1 genotypes of papaya during summer and rainy seasons. Significantly Less number of flower drop was observed in open pollination (0.80) during rainy months. Maximum fruit set $(98.80 \%)$, fruit retention $(96.80 \%)$, Average fruit weight $(0.872 \mathrm{~kg})$ and number of seeds per fruit (438.80) was recorded in open pollination during rainy months when compared to summer and differed significantly with other treatments. Nylon net performs better for more number of seed productions (419.20) in rainy season when compared to summer (345.20) revealing better potential for higher seed production in Papaya (Carica papaya $\mathrm{L})$.
\end{abstract}

\section{Introduction}

Papaya (Carica papaya L.) is an important tropical fruit crop and belongs to the family Caricaceae, which has 48 species. It is a native to Tropical America and believed to be originated in Southern Mexico (De Candolle 1884). Papaya is a polygamous and is highly cross pollinated crop. There are numerous local mixtures everywhere in the country but the relationship of these manifold mixtures among one another has been left unexplained. It is primarily because of high degree of wind and insect pollination up to a distance of several kilometre (Prest, 1955). Though India has developed many elite varieties of papaya, it is observed that the varieties being developed may or may not perform quite satisfactorily when cultivated in other regions of the country, in which environmental factor plays a major role in influencing fruit growth and development. In West Bengal state, commercial cultivation of papaya has gained its momentum due to its wide consumer acceptance, either for its fresh table or vegetable purpose. It has many local strain or 
genotype of papaya which have varied growth and performance. Local Selection-1 is one of the varieties developed which have potential for its yield and quality (Chattopadhyay 2012) as revealed in Figure 1. Seed propagation imparts vigour to the plant which have tendency to become senescent after few years (Singh and Saxena 2008). In papaya, seed with 100 per cent genetic purity is difficult to produce because of the dioecious nature of the plant which essentially enforces cross pollination. Therefore seed should be produced in controlled condition or isolated area (Ram 2009). However, availability of pure seed for commercial cultivation year after years is a major constraint, thereby necessitating the technology to produce sufficiently adequate genetically pure seed to meet the grower demand as standardization and sapling production through tissue culture is yet to create breakthrough. The aim of this study is to investigate the feasibility of caging material for true-to-type seed production of Carica papaya under new alluvial zone of West Bengal.

\section{Materials and Methods}

Field experiment was conducted at Horticulture Research Station, Bidhan Chandra Krishi Viswavidyalaya, Mondouri, Nadia district, West Bengal during the year 2012-2013. The experimental site comes under subtropical humid region. Average temperature ranges from $22.03^{\circ} \mathrm{C}$ to $36.77^{\circ} \mathrm{C}$ during summer months and between $24.20^{\circ} \mathrm{C}$ to $32.66^{\circ} \mathrm{C}$ during rainy months (Table 1). April to June and July to September months were taken as summer and rainy season for experiment in both the years. The experimental design was laid out in Randomized Block Design (RBD) having four treatments Viz. $\mathrm{T}_{1}$ - Covering with perforated (3\%) polyethylene sheet (200gauge) on male and female plants together, $\mathrm{T}_{2}$ - Covering with nylon net $(1.2 \mathrm{~mm})$ on male and female plants together, $\mathrm{T}_{3}-$ Sib mating with perforated butter paper bag $\left(10 \times 12.5 \mathrm{~cm}^{2}\right)$ and $\mathrm{T}_{4}$ - Open pollination (Control) and each treatment was replicated five times. The sib mated seeds of Local Selection-1 were raised in the nursery and transplanted in the main field after 45 days and proper cultural practices were uniformly followed for all the treatments. In each pit four seedlings were planted at a distance of $30 \mathrm{~cm}$ from each other. The seed extraction was done as per the procedure described by Kumar et al., (2010) and Bose et al., (2010). After the emergence of first flower one male and one female plant was retained in each cluster and both the plants were imposed with the four above mentioned treatments. Pollinator such as honey bee along with sugar solution is kept inside for ensuring pollination. Cages were placed separately during summer and rainy on same pair of trees and after taking observations on fix number of flowers, cages were removed. Sib mating was imposed by collecting the pollens from healthy male plants and mixed with 5\% sucrose solution (Nirujogi, 2011) and applied with camel brush on the potential female plants on the same day and the butter paper was covered again tightly at the base of the inflorescence stalk until fruit setting. Whereas the control consisted of natural crossing by open pollination. Observations were recorded for the parameters viz. flower drop (\%), fruit set (\%) fruit retention $(\%)$ average fruit weight $(\mathrm{kg})$ and number of seeds per fruit. Flower drop (\%) drop is expressed dividing the number of flower drop by number of flower bud initiated and expressed in percentage. Fruit set (\%) were recorded seven days after pollination and by dividing number of fruit set per tree ${ }^{-1}$ by number of flowers $^{-1}$ and expressed in percentage. Fruit retention (\%) was also recorded by division of number of fruits up to maturity upon number of fruit set and expressed as percentage. For, average fruit weight, Individual fruit were weigh and expressed in average (kilogram). Number of 
seeds per fruit present in each fruit were counted and expressed as average per fruit. The mean data of the two year was statistically analysed by method of analysis of variance as described by Panse and Sukhatme (1984).

\section{Results and Discussion}

\section{Flower drop (\%)}

The maximum number of fruit drop observed in both the season i.e. Summer (72\%) and rainy $(42 \%)$ was noted when the plants are allowed for pollination inside polyethylene cage and minimum (summer-8\%, rainy-10\%) was noted when flowers are allowed under natural open pollination (Table 2). It was observed that during the summer month the outside maximum temperature were quite high ranging from $37^{\circ} \mathrm{C}$ to $40^{\circ} \mathrm{C}$ and the flower which were allowed to set fruit inside the polyethylene cage faces high humidity with relatively higher temperature. The high temperature prevailing with relatively higher humidity inside the polyethylene cage might had decrease the activity of pollenizer or may cause desiccation or abortment of pollen in the flower. Quite similar study were also reported by Tamaki et al., (2011) while conducting an experiment on seasonal variations flowering, seed and fruit yield in papaya.

\section{Fruit set (\%)}

Fruit set as maximum as 94 per cent was recorded in open pollination during summer season followed by sib mating (91\%), while it was minimum $(29.6 \%)$ in the plants covered with polyethylene cage (Table 2) and significant effect among the treatment was observed. Similar to flower drop, fruit set with higher magnitude was observed during rainy season along with the similar trend recorded after different treatments. It is remarkable to note that only $1 \%$ flower dropping was held during rainy season when open pollination was allowed. Further overall it can be adjudged that the treatment open pollination (control) performs better than the polyethylene cage, nylon net and sib mating, as papaya have various type of visiting pollinator and thereby it contribute to better fruit set and production. Ram (2009) also reported that since pollination in papaya is carried out by insect, the natural crossing of the flowers occurs in an expected consequence. Maximum insect activity is usually seen during rainy season when the plants produce abundant flowers.

This provides enough scope to think that if artificial crossing by hand is done, there would be better chance of getting higher seeds during these months and adjudged that August and September were found to be the best period for fruit and seed development in papaya as the fruit initiated during this period attained better size and contained more seeds. Other factor that might have contributed the greatest effect on fruit set is the positioning of flower within an inflorescence. The basal flower part of the inflorescence set more fruit than the apical portions. Similar work were reported by Lewis and Considine (2010).

\section{Fruit retention $(\%)$}

Fruit retention (\%) was recorded up to maturity. It was of significantly highest magnitude $(96.8 \%)$ in open pollination during rainy season (Table 2). Minimum fruit retention was noticed in polyethylene caged (summer-15.80\%, rainy-27.20\%) fruit followed by nylon net (summer-60.80\%, rainy-66.80\%) during both the season, may be due to unfavourable high temperature confined leading to later stage of embryo abortion within the polyethylene cage. Similar work was reported by Jindal et al., (1993). Similar work was reported by Bhardwaj and Tandon (2013) where fruit retention was less in nylon net in hand emasculated Bael (Aegle marmelos) fruit crops. 
Table.1 Climatic parameter during the experimental period

\begin{tabular}{|c|c|c|c|c|c|}
\hline \multirow[t]{2}{*}{ Month, Year } & \multicolumn{2}{|c|}{ Temperature $\left({ }^{\circ} \mathbf{C}\right)$} & \multirow{2}{*}{$\begin{array}{l}\text { Total Rainfall } \\
(\mathrm{mm})\end{array}$} & \multicolumn{2}{|c|}{ Relative humidity (\%) } \\
\hline & Maximum & Minimum & & Maximum & Minimum \\
\hline April, 2012 & 35.02 & 22.03 & 45.9 & 94.6 & 56.69 \\
\hline May, 2012 & 36.36 & 26.10 & 112 & 89.29 & 64.26 \\
\hline June, 2012 & 34.4 & 26.3 & 127 & 90.4 & 69.3 \\
\hline July, 2012 & 32.6 & 25.8 & 267.5 & 94.2 & 75 \\
\hline August, 2012 & 32.2 & 25.5 & 380.2 & 95 & 78 \\
\hline September, 2012 & 31.17 & 24.20 & 7.90 & 90.38 & 76.96 \\
\hline April, 2013 & 36.77 & 23.45 & 23.56 & 90.33 & 47.23 \\
\hline May, 2013 & 34.45 & 24.53 & 15.96 & 92.87 & 73.96 \\
\hline June, 2013 & 33.78 & 25.18 & 17.62 & 94.1 & 79.8 \\
\hline July, 2013 & 32.66 & 25.34 & 85.23 & 95.19 & 81.90 \\
\hline August, 2013 & 31.66 & 24.34 & 13.92 & 96.77 & 83.52 \\
\hline September, 2013 & 32.47 & 24.51 & 7.71 & 95.63 & 81.50 \\
\hline
\end{tabular}

(Source: Department of Agro-meteorology and Physics, BCKV)

Table.2 Number of flower dropped, fruit set (\%), fruit retention (\%), fruit weight $(\mathrm{kg})$ and Number of seeds/fruit both during summer and rainy season

\begin{tabular}{|c|c|c|c|c|c|c|c|c|c|c|c|}
\hline \multirow[t]{2}{*}{ Trt. } & \multirow[t]{2}{*}{ Name of the treatment } & \multicolumn{2}{|c|}{$\begin{array}{l}\text { No. of fruit } \\
\text { drop }\end{array}$} & \multicolumn{2}{|c|}{ Fruit set $(\%)$} & \multicolumn{2}{|l|}{$\begin{array}{l}\text { Fruit } \\
(\%)\end{array}$} & \multicolumn{2}{|c|}{$\begin{array}{l}\text { Average fruit weight } \\
\text { (kg) }\end{array}$} & \multicolumn{2}{|c|}{$\begin{array}{l}\text { No. of } \\
\text { seeds/fruit }\end{array}$} \\
\hline & & Summer & Rainy & Summer & Rainy & Summer & Rainy & Summer & Rainy & Summer & Rainy \\
\hline $\mathrm{T1}$ & Polyethylene Cage & 72.00 & 42.00 & 29.60 & 53 & 15.80 & 27.20 & 0.665 & 0.722 & 134.40 & 172.80 \\
\hline $\mathrm{T} 2$ & Nylon net & 36.00 & 28.00 & 66 & 72.40 & 60.60 & 66.80 & 0.731 & 0.795 & 345.20 & 419.20 \\
\hline T3 & Sibmating & 10.00 & 12.00 & 91 & 95 & 83.80 & 91 & 0.800 & 0.827 & 186.00 & 206.40 \\
\hline $\mathrm{T4}$ & Open pollination (control) & 8.00 & 10.00 & 94 & 98.60 & 91.60 & 96.80 & 0.820 & 0.872 & 363.80 & 438.80 \\
\hline & CD@5\% & 8.44 & 12.07 & 4.04 & 3.71 & 3.45 & 4.34 & 0.044 & 0.024 & 4.73 & 7.63 \\
\hline & SEm & 2.74 & 3.92 & 1.31 & 1.20 & 1.12 & 1.41 & 0.014 & 0.008 & 1.54 & 2.48 \\
\hline & Significant at $5 \%$ level & $*$ & $*$ & $*$ & $*$ & $*$ & $*$ & $*$ & * & $*$ & $*$ \\
\hline
\end{tabular}

*-Significant 


\section{Average fruit weight (kg)}

In both the season (Summer-0.820kg, rainy$0.872 \mathrm{~kg}$ ), open pollination (control) was found to have maximum fruit weight $(\mathrm{kg})$ followed by sibmating (Summer- $0.800 \mathrm{~kg}$, rainy- $0.827 \mathrm{~kg}$ ) (Table 2). The average increase in fruit weight may be due to the the normal fruit development and its dependency upon the presence of sufficient number of seeds in the fruit. Strong relationship existed between the final size of the fruit and the number of fully developed seeds it contained. This may be due to the effect of the developing seeds that produce auxin and thereby act upon the growth of the pericarp tissue (Ram, 2009). Other factor that may has also influenced better fruit weight is due to important climatic factors i.e. temperature and soil moisture affecting fruit production in papaya Nakasone (1986).

\section{No. of seeds/fruit}

Maximum number of seeds/fruit was recorded after plants were allowed for open pollination (Table 1) irrespective of the season and it was of lowest minimum value when plants were grown within polyethylene cage. Critical observation on this parameter after the individual treatment enlighten breaking information wherein higher number of seeds (419.2) were recovered from fruit of those plants grown within nylon net during rainy season respectively, which were far higher than that recovered after sibmating. Number of seeds recovered after sibmating is comparatively less, which may be due to less number of fertilization with limited number of artificial pollen supply. High number of seed setting in open pollination and nylon net may be due to favourable optimum temperature Lowest number of seed set within polyethylene cage was probably due to lacking of sufficient number of pollinating agent and unfavourable environmental condition created within the cage. Ram and Ray (1992) also reported that optimum temperature $\left(27.3-29.7^{\circ} \mathrm{C}\right)$ occurrence during rainy season favour higher number of seeds and set fruits comparing to other months and also attributed to the salubrious environment (temperature, relative humidity and soil temperature).

\section{Acknowledgment}

Author is grateful to the and Dean and Head of the department, Fruits and Orchard Management, Faculty of Horticulture, Bidhan Chandra Krishi Viswavidyalaya, West Bengal for allowing to conduct research.

\section{References}

Bharadwaj, V. and Tandon, R. 2013. Selfincompatibility and post-fertilization maternal regulation cause low fecundity in Aegle marmelos (Rutaceae). Bot. J.Linnean. Soc. 172 (4): 572-585

Bose, B., Nigam, V.P., and Sharma, M.K. 2010. Seed soaking treatment with nitrate salts vis a vis physiology of germination and seedling vigor in rice (Oryza sativa L. var. Ratna). Int. J. Agric. Sci. 6 (2): 564-568.

Chattopadhyay, A. 2013.Genetical studies in papaya with regard to improvement in yield and disease resistance, West Bengal, India, Ph.D. Thesis, Bidhan Chandra Krishi Viswavidyalaya, Mohanpur, India.

De Candolle, A. 1884. Origin of cultivated plants. New York. Hafner.

Kumar, R.M.V., Shashidhar, S.D., Kurdikeri, M.B., Chanaveerswami, A.S., and Hosmani. 2010. Influence of harvesting stages on seed yield and quality in Paprika Chilli (Capsicum annuиm L). Seed Res. 30 (1): 99-103.

Lewis, D.H., and Considine, J.A. 2010. Pollination and fruit set in the tamarillo 
(Cyphomandra betacea (Cav.) Sendt.). New Zealand. J. Crop. Hort. Sci. 27 (2): $113-123$.

Nakasone, H.Y., Crozier, J.A., and Ikehara, D.K. 1972. Evaluation of Waimanalo, a new papaya strain. Technical bulletin, Hawaii agricultural experiment station. Hawaii Univ, 79: 12.

Nirujogi, B. 2011. Intergeneric crossing, intervarietal progeny evaluation and mutagenicstudies in papaya (carica papaya L.) [Master's thesis]. Bangalore, Karnataka, India, M.Sc. Thesis, University of Agricultural Sciences. Bangalore, India.

Panse, V. G., and Sukhatme, P.V. 1984. In: Statistical Methods for Agricultural
Workers, Indian Council of Agricultural Research. New Delhi Pp.359.

Prest, R.L. 1955. Unfruitfulness in papaya. QdAgric J. 81:144-148.

Ram, M. 2009. Papaya. ICAR New Delhi.

Ram, M., and Ray, PK. 1992. Influence of fruiting season on seed production of papaya under North Bihar. Seed Res. 20: 81-84.

Tamaki, M., Urasaki, N., Sunakawa, Y. and Motomura, K. 2011. Seasonal variations in pollen germination ability, reproductive function of pistils, seeds and fruit yield in papaya (Carica papaya L.) in Okinawa J. Japan. Soc. Hort. Sci. 80 (2): 156-163.

\section{How to cite this article:}

Uchoi, J., Ezekiel Reang and Sarkar, S.K. 2018. Feasibility of Caging Material for True-ToType Seed Production in Papaya (Carica papaya L.) under New Alluvial Zone of West Bengal, India. Int.J.Curr.Microbiol.App.Sci. 7(06): 1040-1045. doi: https://doi.org/10.20546/ijcmas.2018.706.123 